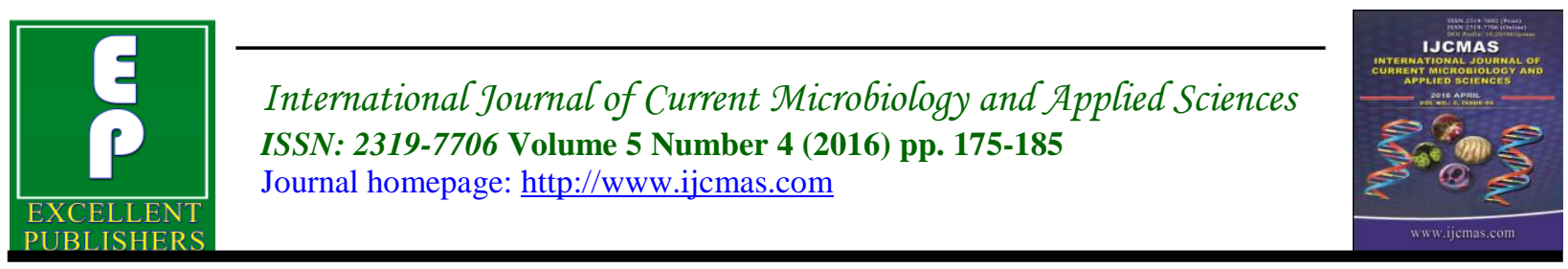

Original Research Article

http://dx.doi.org/10.20546/ijcmas.2016.504.022

\title{
Evaluation of Microbial Adhesion to Contact Lenses
}

\author{
Rania Abdelmonem Khattab ${ }^{1}$, Alaa El-Din Shawky Hosny ${ }^{1}$ and Nahla Mostafa Amer ${ }^{2}$ \\ ${ }^{1}$ Microbiology and Immunology Department, Faculty of Pharmacy, \\ Cairo University, Kasr Al-Aini 11562, Cairo, Egypt \\ ${ }^{2}$ Police Authority Hospital, Giza, Egypt \\ *Corresponding author
}

\section{A B S T R A C T}

Keywords

Contact

Lenses, adherence, MTT.

Article Info

Accepted:

15 March 2016

Available Online:

10 April 2016
The aim of the current study is the study of different parameters affecting the process of adherence of different bacterial species known to be involved in eye infection due to the use of contact lenses. Ninety patients with clinical evidence of microbial keratitis who attended the outpatient clinic corneal unit department of the Research Institute of Ophthalmology, Giza, Egypt were investigated in our study. The biofilm formation was determined using the biochemical methyl tetrazolium bromide (MTT)[(3-(4, 5-dimethyl thiazole-2-yl)-2, 5-diphenyl tetrazolium bromide]. Different factors influencing bacterial adhesion were studied. Thirty Pseudomonas aeruginosa isolates and fifteen Staphylococcus aureus isolates exhibited adherence capability to contact lenses. Pseudomonas aeruginosa adhered at higher number compared to Staphylococcus aureus. Inoculum size was the greatest influencing factor for $P$. aeruginosa adhesion, followed by incubation period and assay media.

\section{Introduction}

Contact lenses provide several benefits over spectacles, but their wear has remained as a risk factor for the development of various adverse events, such as microbial keratitis (MK) (Green et al., 2008), contact lens related acute red eye (CLARE) (Holden et al., 1996), contact lens peripheral ulcer (CLPU) (Wu et al., 2003) and infiltrative keratitis (IK) (Willcox et al., 2011). Adhesion and colonization by variety of microbes, particularly bacteria, to contact lenses is implicated as a major factor in the initiation of these adverse events. Pseudomonas aeruginosa and
Staphylococcus aureus are the two predominant microorganisms implicated in contact lens related microbial adverse events (Otri et al., 2012) and other microorganisms such as Serratia marcescens, coagulasenegative staphylococci, fungus (Tuli et al., 2007) and Acanthamoeba (Yoder et al., 2012) are less frequently involved. Depending on the study design and location, $P$. aeruginosa and $S$. aureus together account $44 \%$ to $57 \%$ of total culture positive contact lens related microbial keratitis (Keay et al., 2006). Adhesion of pathogenic microbes, particularly bacteria, to contact 
lenses is implicated in contact lens related microbial adverse events. Various in vitro conditions such as type of bacteria, the size of initial inoculum, contact lens material, nutritional content of media, and incubation period can influence bacterial adhesion to contact lenses (Debarun et al., 2013). The aim of the current study is the study of different parameters affecting the process of adherence of different bacterial species known to be involved in eye infection due to the use of contact lenses.

\section{Materials and Methods}

\section{Study Population}

Our study included 90 (60males and 30 females) patients with clinical evidence of microbial keratitis who attended the outpatient clinic corneal unit department of the Research Institute of Ophthalmology, Giza, Egypt. A detailed history was taken and a thorough slit-lamp examination was done for all patients. Associated ocular conditions such as blepharitis, conjunctivitis, dacryocystitis, dry eyes and lid abnormalities were documented. The use of contact lenses and of topical corticosteroids and other systemic combinations were also recorded. In patients with infective keratitis, the size, depth and margins of the infiltrate were noted. Satellite lesions and hypopyon were documented. Any epithelial defect was photographed and measured. Corneal scrapings were taken from the base and edge of the ulcers under aseptic techniques, with a sterile blade, after installing local anesthetic solution (4\% xylocaine) in the eye.

\section{Clinical Procedures (Scrape Technique)}

The material obtained by scraping from the leading edge and the base of each ulcer was spread onto labeled slides in a thin, even manner for Gram staining. Also the scraping material obtained from each ulcer was inoculated directly onto sheep's blood agar, chocolate agar, and Sabouraud dextrose agar (SDA) in a row of C-shaped streaks so that contamination could be spotted outside the $\mathrm{C}$ streaks and discarded. Deep inoculation in brain heart infusion broth was also done.

\section{Laboratory Procedures}

All inoculated media were incubated aerobically. The inoculated blood agar, chocolate agar, and brain heart infusion broth were incubated at $37^{\circ} \mathrm{C}$, examined daily, and discarded after 5 days if no growth was observed. The inoculated Sabouraud dextrose agar was incubated at $27^{\circ} \mathrm{C}$, examined daily and discarded after 14 days if no growth was detected while Wilikins Chalgren anaerobic agar was incubated anaerobically in anaerobic jar at $37^{\circ} \mathrm{C}$ and examined after 5 days. Fungus grown on the primary isolation medium was subcultured onto an SDA medium and incubated for a period of 15 days to facilitate sporulation. Following adequate growth of the fungal isolates on SDA, identification was done based on its macroscopic and microscopic features using lactophenol cotton blue stain solution; where one drop of lactophenol cotton blue solution is put on clean slide, and by the loop a part of the fungi grown on SDA is placed on the slide and then slide cover is placed and examined under conventional microscope by oil immersion lense.

\section{Duration for Isolation of Organisms}

Most aerobic bacteria for keratitis are seen on standard culture media within $48 \mathrm{hrs}$. In some cases pathogen may be recognized in 12 to $15 \mathrm{hrs}$.

Aerobic culture should be held for 5 days, anaerobic culture for 5 days and 14 days for fungal culture. 


\section{Positive Culture}

Microbial cultures were considered significant if growth of the same organism was demonstrated on more than one solid phase medium, and/or if the same organism was grown from repeated scraping. If positive bacterial growth was obtained on the different culture media, the standard biochemical tests were performed and further identification was done up to the species levels using the API STAPH and API 20NE systems.

\section{In-vitro Adherence of the Isolates to Contact Lenses}

\section{Biofilm Formation}

The methodologies described by Ishida $e t$ al., (1998); Baillie and Douglas, (2000); Ramage et al., (2001); and Fraud et al., (2005); for microbial BM formation, were applied with slight modifications.

Biofilms were formed on small pieces of contactlenses. An inoculum preparation corresponding to a concentration of $1.5 \times 10^{8}$ $\mathrm{CFU} / \mathrm{mL}$ or equivalent to $0.5 \mathrm{McF}$ arland densityfor each bacterial, or fungal isolate was used to inoculate $5 \mathrm{ml}$ of Trypticase Soya Broth (TSB), or Yeast Nitrogen Base (YNB); respectively. The $5 \mathrm{ml}$ media in the tubes were inoculated with the specified inoculum, then incubated at $37^{\circ} \mathrm{C}$ for $24 \mathrm{~h}$. After BM formation, the medium was aspirated with a sterilized pasteur pipette.

The non-adherent planktonic, free floating cells were removed by thoroughly washing the BMs four times with $0.15 \mathrm{M}$ sterile phosphate-buffered saline (PBS), PH 7.3. Residual PBS was removed by blotting with paper towels before the evaluation of adherence.

\section{Measurement of Biofilm Formation}

The biofilm formation was determined as described by Chandra et al., (2001); and Kuhn et al., (2002a \&2002b); using the biochemical methyl tetrazolium bromide (MTT) reduction assay method.

This method is based on the fact that MTT (methyl tetrazolium bromide) [(3- $(4,5-$ dimethyl thiazole-2-yl)-2, 5-diphenyl tetrazolium bromide]which is colorless, water-soluble chemical, could be reduced by the microbial dehydrogenase enzyme into a violet, water-insoluble formazon product (Kuhn et al., 2002a,b). This product in turn could be measured either qualitatively or quantitatively.

\section{Preparation of the MTT Solution}

The MTT was prepared as stock solution $1 \mathrm{mg} / \mathrm{ml}$ in PBS PH 7.2. For qualitative and quantitative determination of adherence, we reconstituted each polystyrene tube with 2 $\mathrm{ml}$ of fresh YNB supplemented with 100 $\mathrm{ug} / \mathrm{ml}$ of MTT.

\section{Qualitative Determination of Biofilms}

To the pre-formed BMs $2 \mathrm{ml}$ of fresh TSB medium incase of bacterial isolates or YNB medium incase of Candida isolates were added. Each tube was then supplemented with $100 \mathrm{ug} / \mathrm{ml}$ MTT solution.

Two types of control tubes were needed:

I- Control for biofilm formation: tubes not subjected to BM formation were supplemented with the MTT solutions.

II- Control for the reduction of MTT solution: tubes were devoided of the MTT solution. 
All tubes were incubated at $37^{\circ} \mathrm{C}$ for $4 \mathrm{~h}$, and then the medium was carefully removed by aspiration. The acrylate pieces were observed for the violet color of formazon. Results were recorded for each isolate according to the color intensity, ranging from non-adherent to weakly or highly adherent isolates.

\section{Quantitation of Biofilms}

Same procedure as presented under (6.2.b) was carried out. In this case the violet color of formazon was constructed as a liquid to be quantitated. After incubation at $37^{\circ} \mathrm{C}$ for $4 \mathrm{~h}$ as done for qualitative assay (6.2b), the $\mathrm{BM}$ was dislodged by sonication at $30 \%$ cycle, 3.5 output for $30 \mathrm{sec}$. The tubes were centrifuged at $3000 \mathrm{rpm}$ for $15 \mathrm{~min}$, then the supernatant is remove carefully. The sediments in tubes were suspended in $2 \mathrm{ml}$ portions of isobutyl alcohol and the tubes were shaked for $1 \mathrm{~h}$ at room temperature to extract the formazon. After $15 \mathrm{~min}$ of centrifugation, the formazon in the supernatant was measured spectrophotometrically at $550 \mathrm{~nm}$.

\section{Factors Influencing Bacterial Adhesion}

\section{Assay Media}

Four different types of bacterial suspension media, phosphate buffered saline $\mathrm{pH} 7.4$ (PBS; $\mathrm{NaCl} 8 \mathrm{~g} / \mathrm{L}, \mathrm{KCl} 0.2 \mathrm{~g} / \mathrm{L}$, Na2HPO4 1.15 g / L, KH2PO4 0.2 g/ L), tryptone soy broth, TSB diluted $10 \mathrm{X}$ in sterile PBS (1/10 TSB), or $1 / 10$ TSB containing glucose $(0.25 \% \mathrm{w} / \mathrm{v})$ (TSBG) were used. PBS acted as a nutritionally inert media and TSB as a highly nutritious media.

\section{Incubation Period}

Contact lenses were incubated for two hours and 18 hours with the bacterial suspensions.

\section{Inoculum Size}

$1 \times 10^{3} \mathrm{CFU} / \mathrm{mL}, 1 \times 10^{6} \mathrm{CFU} / \mathrm{mL}$ and 1 $\times 10^{10} \mathrm{CFU} / \mathrm{mL}$ are the three inoculum sizes used in this study.

\section{Results and Discussion}

\section{Identification and Characterization of Clinical Isolates}

A total of 80 bacterial isolates belonging to the genera Staphylococcus and Pseudomonas, as well as 10 fungal isolates of Candida species, were collected. Fourtyeight isolates represent Staphylococcus species, of which 32 were identified as $S$. aureus, 9 isolates as S. epidermidis and 7 isolates were classified as unidentified Staphylococcus species. Thirty two of the isolates were confirmed to be Pseudomonas aeruginosa. The supplied isolates were identified up to the species levels using the API systems. As for the fungal isolates, the 10 fungal isolates were found to belong to Candida species.

\section{Adherence of Bacterial Isolates to Contact Lenses}

The bacterial isolates were tested for their adherence capability using the MTT reduction assay method. Thirty $P$. aeruginosa isolates and fifteen Staphylococcus aureus isolates exhibited adherence capability to contact lenses, tables $1 \mathrm{a}$ and $1 \mathrm{~b}$ respectively. In all of the 80 tested bacterial isolates of the genus Staphylococcus, and $P$. aeruginosa, the assay for adherence to contact lenses was found to be quite reproducible. Figure 1 shows the percentage of bacterial isolates showing adherence to contact lenses. Adherence was evaluated spectrophotometrically by the absorbance of the formazon's violet color at $550 \mathrm{~nm}$ wavelength. In this respect $56 \%$ (45) of the 80 bacterial isolates were considered of high 
adherence capability giving absorbance range of 0.936 to 1.868 . The distribution of bacterial isolates giving absorbance in the above-mentioned range is as follows: Pseudomonas aeruginosa (37.5\%) and $S$. aureus (18.75\%).

\section{Adherence of Candida Species to Contact Lenses}

The 10 isolated Candida species were tested qualitatively and quantitatively for their adherence capability. All of these species showed negative adherence capability.

\section{Factors Influencing Bacterial Adhesion}

Pseudomonas aeruginosa adhered at higher number compared to $S$. aureus. For each bacterial type there was a significant increase in adhesion from 2 to 18 hours when incubated with $1 \times 10^{3} \mathrm{CFU} \mathrm{m} / \mathrm{L}$ or 1 $\times 10^{6} \mathrm{CFU} \mathrm{m} / \mathrm{L}$ bacterial suspension. For $P$. aeruginosa strains, adhesion to the contact lenses increased as the initial inoculum increased. However, for strains of $S$. aureus adhesion reached a maximum when $1 \times 10^{6}$ $\mathrm{CFU} / \mathrm{mL}$ bacterial cells were incubated with lenses; addition of bacteria at $1 \times 10^{10} \mathrm{CFU} /$ $\mathrm{mL}$ did not increase adhesion. When comparing the effect of different media on adhesion, there were differences between the bacterial genera/species.

Table.1a Adherence of Pseudomonas aeruginosa Isolates to Contact Lenses

\begin{tabular}{|c|c|}
\hline Isolate & $\begin{array}{c}\text { Quantitative } \\
\text { assay for adherence to } \\
\text { acrylate derivatives }\end{array}$ \\
\hline P. aeruginosa 1 & 1.130 \\
\hline P. aeruginosa 2 & 1.594 \\
\hline P. aeruginosa 3 & 1.181 \\
\hline P. aeruginosa 4 & 1.157 \\
\hline P. aeruginosa 5 & 1.131 \\
\hline P. aeruginosa 6 & 1.135 \\
\hline P. aeruginosa 7 & 1.167 \\
\hline P. aeruginosa 8 & 1.520 \\
\hline P. aeruginosa 9 & 1.762 \\
\hline P. aeruginosa 10 & 1.121 \\
\hline P. aeruginosa 11 & 1.159 \\
\hline P. aeruginosa 12 & 1.055 \\
\hline P. aeruginosa 13 & 1.067 \\
\hline P. aeruginosa 14 & 1.277 \\
\hline P. aeruginosa 15 & 1.019 \\
\hline P. aeruginosa 16 & 1.811 \\
\hline P. aeruginosa 17 & 1.750 \\
\hline P. aeruginosa 18 & 1.655 \\
\hline P. aeruginosa 19 & 1.633 \\
\hline P. aeruginosa 20 & 1.815 \\
\hline P. aeruginosa 21 & 1.868 \\
\hline P. aeruginosa 22 & 1.527 \\
\hline P. aeruginosa 23 & $\mathbf{1 . 0 7 5}$ \\
\hline P. aeruginosa 24 & 1.175 \\
\hline P. aeruginosa 25 & 1.072 \\
\hline P. aeruginosa 26 & 1.091 \\
\hline P. aeruginosa 27 & 1.086 \\
\hline P. aeruginosa 28 & 1.859 \\
\hline P. aeruginosa 29 & 1.033 \\
\hline P. aeruginosa 30 & 1.327 \\
\hline
\end{tabular}


Table.1b Adherence of Staphylococcus aureus Isolates to Contact Lenses

\begin{tabular}{|c|c|}
\hline Isolates & $\begin{array}{c}\text { Quantitative } \\
\text { assay for adherence } \\
\text { to acrylate } \\
\text { derivatives } * *\end{array}$ \\
\hline S. aureus 1 & 1.135 \\
\hline S. aureus 2 & 1.112 \\
\hline S. aureus 3 & $\mathbf{1 . 2 3 8}$ \\
\hline S. aureus 4 & $\mathbf{1 . 1 7 0}$ \\
\hline S. aureus5 5 & $\mathbf{1 . 4 5 0}$ \\
\hline S. aureus 6 & $\mathbf{1 . 2 7 9}$ \\
\hline S. aureus 7 & $\mathbf{1 . 2 0 9}$ \\
\hline S. aureus 8 & $\mathbf{1 . 3 0 5}$ \\
\hline S. aureus 9 & $\mathbf{1 . 8 0 1}$ \\
\hline S. aureus 10 & $\mathbf{1 . 1 4 0}$ \\
\hline S. aureus11 & $\mathbf{1 . 1 8 4}$ \\
\hline S. aureus 12 & $\mathbf{0 . 9 3 6}$ \\
\hline S. aureus13 & $\mathbf{1 . 1 2 4}$ \\
\hline S. aureus 14 & $\mathbf{0 . 9 7 0}$ \\
\hline S. aureus 15 & $\mathbf{0 . 9 8 4}$ \\
\hline
\end{tabular}

Figure.1 Percentage of Bacterial Isolates Showing Adherence to Contact Lenses

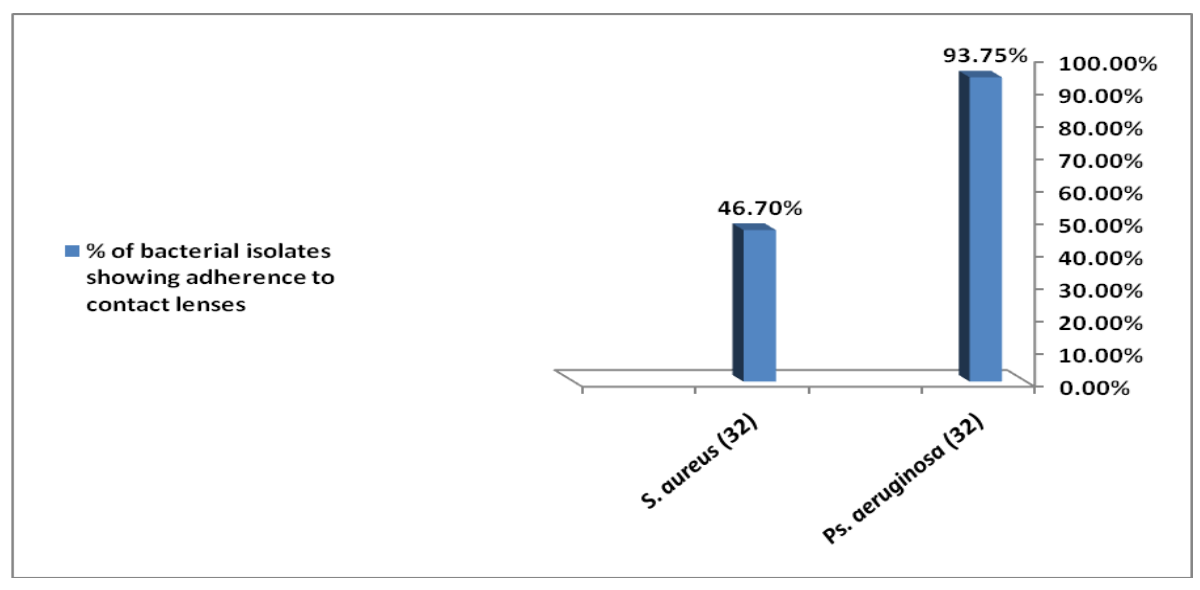

For $P$. aeruginosa, adhesion was significantly lower when incubated in PBS after 18 hours for concentrations up to and including $1 \times 10^{6} \mathrm{CFU} / \mathrm{mL}$, but not at $1 \times$ $10^{10} \mathrm{CFU} / \mathrm{mL}$. At $1 \times 10^{3} \mathrm{CFU} / \mathrm{mL}$ adhesion of $P$. aeruginosa was significantly higher when incubated with TSB compared to all other media, but this difference tended to lose significance at higher bacterial concentrations. For S. aureus, adhesion was significantly lower in PBS than all other media at all bacterial concentrations, at all time points.

When $1 \times 10^{6}$ or $1 \times 10^{10} \mathrm{CFU} / \mathrm{mL}$ of $S$. aureus was used, there was a reduction in bacterial numbers adhered to lenses when incubated in PBS after 18h adhesion compared to 2 hours adhesion; this was not the case with other media. After adjusting for effects of incubation time and inoculum size, incubation with PBS showed significantly less adhesion for all the bacteria studied. There were no significant 
differences in bacterial adhesion when incubated with $1 / 10$ TSB or TSBG. Incubation in the nutritionally rich TSB was often associated with higher adhesion compared to other media especially after 18 hours.

Pseudomonas aeruginosa adhered at higher levels than $S$. aureus and this is in agreement with the previous reports (Borazjani, 2004; Zhang et al., 2005). However, the reason is not known in any great detail. It is known that cell surface appendages such as flagella and pili aid in the adhesion of $P$. aeruginosa (Tran et al., 2011) as does the relatively hydrophobic nature of some strains of $P$. aeruginosa compared to $S$. aureus (Bruinsma et al., 2001). This finding has been hypothesized to be a reason for the finding that $P$. aeruginosa is a predominant causative agent in contact lens induced-MK. Previous studies have elucidated that the initial bacterial adhesion to contact lenses increases with time, peaked at 3 to 18 hours of incubation and then remained steady, suggesting the end point of primary adhesion (Randler et al., 2010; Miller et al., 1987; Andrews et al., 2001). Bacterial adhesion during two phases of the process, two hours and 18 hours exposure of contact lenses to bacterial suspension were determined in this study. The viable bacterial numbers after 18 hours adhesion were generally higher compared with after 2 hours, an observation that agrees with some previous studies (Szczotka-Flynn et al., 2009). Combining our results with Tran et al., showing linear kinetics of bacterial adhesion up to 70 minutes and Randler et al., (21) investigating up to 72 hours but having incremental adhesion only up to 24 hours, illustrates that adhesion to contact lenses increases in a time dependant manner up to 18-24 hours of incubation and then viability is reduced. Perhaps, the reduction in viability is due to the bacteria entering a biofilm mode of growth, which is known to result in lower viability of cells or due to biofilm dispersal that can occur when the environment nutrients are not favorable for bacteria. In contrast, Stapleton et al., (1993) and Andrews et al., (2001) reported a plateau in adhesion that was reached after 45 minutes and four hours incubation respectively, with the adhesion that remained at those levels for more than 18 hours. These findings illustrates that investigators need to select incubation period of a bacterial adhesion carefully, depending upon study hypothesis being tested.

Bacterial incubation in the nutritionally rich media TSB resulted in the highest adhesion of both bacterial types. PBS, being nutritionally inert, resulted in apparent death or the more fastidious $S$. aureus strains used in the current study, and so PBS is not recommended as a media for adhesion experiments. This study demonstrates that diluted TSB can function as an adequate media for adhesion experiments. Since there was no significant difference in bacterial adhesion with 1/10 TSB and TSBG, addition of glucose is not recommended. Since it is difficult to quantify exposure of contact lenses to microorganisms during wear, a wide range of numbers were selected for testing; $1 \times 10^{3} \mathrm{CFU} / \mathrm{mL}$ represented a low inoculum size, $1 \times 10^{6} \mathrm{CFU} / \mathrm{mL}$ a medium inoculum size and $1 \times 10^{10} \mathrm{CFU} / \mathrm{mL}$ represented very high inoculum size. $1 \times$ $10^{10} \mathrm{CFU} / \mathrm{mL}$ was usually associated with highest adhesion, especially when incubated for 2 hours. Previous studies have also used higher inoculum sizes when incubation times were short and a lower inoculum size when incubated for longer. Contact lenses will rarely be exposed to such high numbers of bacteria such as $1 \times 10^{10} \mathrm{CFU} / \mathrm{mLduring}$ contact lens wear or even in lens cases. The 
range of bacterial numbers isolated from contact storage lens storage cases has been reported to be $1.24 \times 10^{4} \mathrm{CFU} /$ case to $6.32 \times$ $10^{4} \mathrm{CFU} /$ case. Therefore, exposing contact lenses to this level of bacteria may be unrealistic. The data from the current experiments suggest that an inoculum size of $1 \times 10^{6} \mathrm{CFU} / \mathrm{mL}$ may offer a more realistic level of bacteria to expose contact lenses to, and results in medium to high levels of bacterial adhesion.

Inoculum size was the greatest influencing factor for $P$. aeruginosa adhesion, followed by incubation period and assay media. Interestingly, nutritionally variable assay media was the greatest influencing factor determining $S$. aureus adhesion, confirming that $S$. aureus is sensitive to the nutritional content. Incubation period and inoculum size were the other major influencing factors. A limitation of this study is that bacterial adhesion to contact lens was not evaluated at frequent time intervals, which might have provided better understanding regarding kinetics of bacterial adhesion. Bacterial adhesion after longer incubation period such as 18 hours is complex procedure because of the bacteria are more likely to be replicating during this time, especially under nutrient enhanced conditions, probably combinations of initial biofilm formation and continued initial adhesion of daughter cells. Based on the results obtained in this study we suggest 18 hours incubation of $10^{6} \mathrm{CFU} \mathrm{mL} / 1 \mathrm{~S}$. aureus or $P$. aeruginosa in $1 / 10$ TSB or PBS respectively to study the attachment of bacteria to contact lenses. The advantages of this recommended assay also include that better results could be achieved with the use of basic laboratory apparatuses and does not require expensive machines such as confocal or optical microscope and microtitre plate reader. It is important to carefully select assay conditions depending on the study purpose.

In conclusion, Pseudomonas aeruginosa adhered in higher numbers compared to Staphylococcus aureus. The size of initial inoculum, nutritional content of media, and incubation period played significant roles in bacterial adhesion to lenses. A set of invitro assay conditions to help standardize adhesion between studies have been recommended. This study has determined that adhesion is more affected by the environment and numbers of bacteria initially applied to lenses.

\section{References}

Andrews, C.S., Denyer, S.P., Hall, B., Hanlon, G.W., Lloyd, A.W. 2001. A comparison of the use of an ATPbased bioluminescent assay and image analysis for the assessment of bacterial adhesion to standard HEMA and biomimetic soft contact lenses. Biomaterials, 22: 3225-3233.

Baillie, G.S., Douglas, L.J. 2000. Matrix polymers of Candida albicans biofilms and their possible role in biofilm resistance to antifungal agents. J. Antimicrob. Chemother., 46: 397-403.

Bandara, B.M.K., Sankaridurg, P.R., Willcox, M.D.P. 2004. Non-steroidal anti inflammatory agents decrease bacterial colonisation of contact lenses and prevent adhesion to human corneal epithelial cells. Curr. Eye Res., 29: 245-251.

Borazjani, R. 2004. Relative primary adhesion of Pseudomonas aeruginosa, Serratia marcescens and Staphylococcus aureus to HEMAtype contact lenses and an extended wear silicone hydrogel contact lens of high oxygen permeability. Cont. Lens Anterior Eye, 27: 3-8. 
Bruinsma, G.M., van der Mei, H.C., Busscher, H.J. 2001. Bacterial adhesion to surface hydrophilic and hydrophobic contact lenses. Biomaterials, 22: 3217-3224.

Chandra, J., Mukherjee, P.K., Leidich, S.D., Faddoul, F.F., Hoyer, L.L., Douglas, L.J., Ghannoum, M.A. 2001. Antifungal resistance of Candida biofilms formed on denture acrylic in-vitro. J. Dent. Res., 80: 903-908.

Dantam, J., Zhu, H., Willcox, M., Ozkan, J., Naduvilath, T., Thomas, V., Stapleton, F. 2012. In vivo assessment of antimicrobial efficacy of silver-impregnated contact lens storage cases. Invest. Ophthalmol. Vis. Sci., 53: 1641-1648.

Debarun, D., Mark, D.P.W. 2013. A Laboratory Assessment of Factors That Affect Bacterial Adhesion to Contact Lenses. Biol., 2: 1268-1281.

Donlan, R.M., Costerton, J.W. 2013. Biofilms: Survival mechanisms of clinically relevant microorganisms. Clin. Microbiol. Rev., 15: 167-193. Biol., 2: 1281.

Donzis, P.B., Mondino, B.J., Weissman, B.A., Bruckner, D.A. 1987. Microbial contamination of contact lens care systems. Am. J. Ophthalmol., 104: 325-333.

Evans, D.J., Allison, D.G., Brown, M.R., Gilbert, P. 1990. Effect of growthrate on resistance of gram-negative biofilms to cetrimide. J. Antimicrob. Chemother., 26: 473-478.

Fleiszig, S.M., Efron, N. 1992. Microbial flora in eyes of current and former contact lens wearers. J. Clin. Microbiol., 30: 1156-1161.

Fraud, S., Maillard, J.V., Kaminski, M.A., Hanlon, G.W. 2005. Activity of amine oxide against biofilms of Streptococcus mutans: a potential biocide for oral care formulations. $J$.
Antimicrob. Chemother., 56(4): 672677.

Green, M., Apel, A., Stapleton, F. 2008. Risk factors and causative organisms in microbial keratitis. Cornea, 27: 22-27.

Holden, B.A.; La Hood, D., Grant, T., Newton-Howes, J., Baleriola-Lucas, C., Willcox, M.D., Sweeney, D.F. 1996. Gram-negative bacteria can induce contact lens related acute red eye (CLARE) responses. CLAO J., 22: 47-52.

Ishida, H., Ishida, Y., Kurosaka, Y., Otani, T., Sato, K., Kobayashi, H. 1998. Invitro and in-vivo activities of levofloxacin against biofilmproducing Pseudomonas aeruginosa. Antimicrob. Agents Chemother., 42(7): 1641-1645.

Keay, L., Edwards, K., Naduvilath, T., Forde, K., Stapleton, F. 2006. Factors affecting the morbidity of contact lens-related microbial keratitis: A population study. Invest. Ophthalmol. Vis. Sci., 47: 43024308.

Kuhn, D.M., Chandra, J., Mukherjee, P.K., Ghannoum, M.A. 2002a. Comparison of biofilms formed by Candida albicans and Candida parapsilosis on bioprothetic surfaces. Infect. Immun., 70: 887-898.

Kuhn, D.M., George, T., Chandra, J.; Mukherjee, P.K., Ghannoum, M.A. 2002b. Antifungal susceptibility of Candida biofilms: unique efficacy of amphotricin B lipid formulations and echinocandins. Antimicrob. Agents Chemother., 46(6): 1773-1780.

Miller, M.J., Ahearn, D.G. 1987. Adherence of Pseudomonas aeruginosa to hydrophilic contact lenses and other substrata. J. Clin. Microbiol., 25: 1392-1397.

Miller, M.J., Wilson, L.A., Ahearn, D.G. 
1988. Effects of protein, mucin, and human tears on adherence of Pseudomonas aeruginosa to hydrophilic contact lenses. J. Clin. Microbiol., 26: 513-517.

Otri, A.M., Fares, U., Al-Aqaba, M.A., Miri, A., Faraj, L.A., Said, D.G., Maharajan, S., Dua, H.S. 2012. Profile of sight-threatening infectious keratitis: A prospective study. Acta ophthalmologica.

Pens, C.J., da Costa, M., Fadanelli, C., Caumo, K., Rott, M. 2008. Acanthamoeba spp. and bacterial contamination in contact lens storage cases and the relationship to user profiles. Parasitol. Res., 103: 12411245.

Ramage, G., Walle, K.V., Wickes, B.L., Ribot, J.L. 2001. Standardized method for in-vitro antifungal susceptibility testing of Candida albicans biofilms. Antimicrob. Agents Chemother., 45(9): 24752479.

Randler, C., Matthes, R., McBain, A., Giese, B., Fraunholz, M., Sietmann, R., Kohlmann, T., Hubner, N., Kramer, A. 2010. A three-phase in-vitro system for studying Pseudomonas aeruginosa adhesion and biofilm formation upon hydrogel contact lenses. BMC Microbiol., 9: 12.

Stapleton, F., Dart, J., Matheson, M., Woodward, E. 1993. Bacterial adherence and glycocalyx formation on unworn hydrogel lenses. J. Brit. Contact Lens Assoc., 16: 113-116.

Szczotka-Flynn, L.B., Imamura, Y., Chandra, J., Yu, C., Mukherjee, P.K., Pearlman, E., Ghannoum, M.A. 2009. Increased resistance of contact lens-related bacterial biofilms to antimicrobial activity of soft contact lens care solutions. Cornea, 28: 918926.
Tran, V.B., Fleiszig, S.M., Evans, D.J., Radke, C.J. 2011. Dynamics of flagellum- and pilus-mediated association of Pseudomonas aeruginosa with contact lens surfaces. Appl. Environ. Microbiol., 77: 3644-3652.

Tuli, S.S., Iyer, S.A., Driebe, W.T., Jr. Fungal keratitis and contact lenses: An old enemy unrecognized or a new nemesis on the block, Eye Contact Lens, 33: 415-417.

Willcox, M., Sharma, S., Naduvilath, T.J., Sankaridurg, P.R., Gopinathan, U., Holden, B.A. 2011. External ocular surface and lens microbiota in contact lens wearers with corneal infiltrates during extended wear of hydrogel lenses. Eye Contact Lens, 37: 90-95.

Willcox, M.D., Carnt, N., Diec, J., Naduvilath, T., Evans, V., Stapleton, F., Iskandar, S., Harmis, N., de la Jara, P.L., Holden, B.A. 2010. Contact lens case contamination during daily wear of silicone hydrogels. Optom. Vis. Sci., 87: 456464.

Willcox, M.D., Hume, E.B., Vijay, AK., Petcavich, R. 2010. Ability of silverimpregnated contact lenses to control microbial growth colonisation. $J$. Optom., 3: 143-148.

Williams, T.J., Willcox, M.D., Schneider, R.P. 1998. Interactions of bacteria with contact lenses: The effect of soluble protein and carbohydrate on bacterial adhesion to contact lenses. Optom. Vis. Sci., 75: 266-271.

Wilson, L.A., Sawant, A.D., Simmons, R.B., Ahearn, D.G. 1990. Microbial contamination of contact lens storage cases and solutions. Am. J. Ophthalmol., 110: 193-198.

Wu, P., Stapleton, F., Willcox, M.D. 2003. The causes of and cures for contact 
lens-induced peripheral ulcer. Eye Contact Lens, 29: S63-S66.

Yoder, J.S., Verani, J., Heidman, N., HoppeBauer, J., Alfonso, E.C., Miller, D., Jones, D.B., Bruckner, D., Langston, R., Jeng, B.H., et al., 2012. Acanthamoeba keratitis: the persistence of cases following a multistate outbreak. Ophthalmic Epidemiol., 19: 221-225.
Zhang, S., Borazjani, R.N., Salamone, J.C., Ahearn, D.G., Crow, S.A., Jr., Pierce, G.E. 2005. In vitro deposition of lysozyme on etafilcon A and balafilcon A hydrogel contact lenses: Effects on adhesion and survival of Pseudomonas aeruginosa and Staphylococcus aureus. Cont. Lens Anterior Eye, 28: 113-119.

\section{How to cite this article:}

Rania Abdelmonem Khattab, Alaa El-Din Shawky Hosny and Nahla Mostafa Amer. 2016. Evaluation of Microbial Adhesion to Contact Lenses. Int.J.Curr.Microbiol.App.Sci.5(4): 175185. http://dx.doi.org/10.20546/ijcmas.2016.504.022 